\title{
Kilogram i mol u novome ruhu - o korjenitim promjenama u Međunarodnom sustavu jedinica (SI)
}

\section{Lopac*}

Zavod za fiziku, Fakultet kemijskog inženjerstva i tehnologije, Sveučilište u Zagrebu, Hrvatska

\begin{abstract}
Sažetak
Od 20. svibnja 2019. jedinice Međunarodnog sustava SI definirane su s pomoću sedam prirodnih konstanti, $v_{\mathrm{C} s}, c, h, e_{,} k_{\mathrm{B}}, N_{\mathrm{A}}$ i $K_{\mathrm{cd}}$. Promjene su prihvaćene na 26. sjednici Opće konferencije za utege i mjere (Conférence générale des poids et mesures, CGPM), održanoj u Versaillesu u Francuskoj 18. studenoga 2018. U članku su navedene stare i nove definicije osnovnih jedinica sustava SI, kao i matematički izrazi koji se dobiju rješavanjem algebarskih jednadžbi implicitno sadržanih u novim definicijama. Posebna je pozornost posvećena povijesti i novim definicijama jedinica kilogram i mol te metodičkim aspektima njihova tumačenja. Navedeni su i odabrani numerički primjeri, korisni za primjenu u srednjoškolskoj i sveučilišnoj nastavi kemije.

Ključne riječi

Nastava kemije, Međunarodni sustav jedinica (SI), kilogram, mol, tetraedar, kristalna struktura, silicij-28, prirodne konstante, prirodne jedinice
\end{abstract}

\section{Uvod}

Krajem 2018. godine svijetom se proširila vijest o korjenitoj preobrazbi Međunarodnog sustava jedinica (SI). Posebno uzbuđenje izazvalo je napuštanje prauzorka kilograma koji se od 1889. godine čuvao pod staklenim zvonom u Sèvresu kraj Pariza, kao i uvođenje nove definicije kilograma s pomoću Planckove konstante $h$. Promjene su prihvaćene na 26. sjednici Opće konferencije za utege i mjere (Conférence générale des poids et mesures, CGPM), održanoj u Versaillesu u Francuskoj 18. studenoga 2018., a stupile su na snagu 20. svibnja 2019. ${ }^{1-3}$

Međunarodni sustav jedinica (Système international d'unités, SI) izrastao je iz metarskog sustava uvedenoga u široku upotrebu krajem 18. stoljeća, u vrijeme Francuske revolucije. Utemeljen je na jedinicama metar za duljinu i kilogram za masu. Metar je isprva bio definiran kao četrdeset milijunti dio pariškog meridijana, a kilogram kao masa kubnog decimetra vode. U svojoj suvremenoj formi Međunarodni sustav jedinica (SI) postoji od 1960. Tada je dogovoreno da ga čine već ranije prihvaćene osnovne mjerne veličine - vrijeme, duljina, masa, električna struja, termodinamička temperatura i svjetlosna jakost te njihovih šest pripadnih osnovnih jedinica sekunda, metar, kilogram, amper, kelvin i kandela, dok su sedma veličina, količina (množina) tvari, i njezina jedinica mol dodane tek 1971. godine. Množenjem cjelobrojnih potencija osnovnih jedinica nastaju brojne izvedene jedinice. Neke od njih imaju

* Prof. dr. sc. Vjera Lopac, redoviti profesor u trajnom zvanju, u mirovini, e-pošta:vlopac@fkit.hr posebna imena, a one koje su dobivene izravnim množenjem osnovnih jedinica bez dodatnih numeričkih faktora nazivaju se koherentnim jedinicama.

Jedna od prednosti metarskog sustava jest decimalni sustav iskazan popisom predmetaka (višekratnika i nižekratnika), koji omogućuje jednostavno prikazivanje većih i manjih iznosa. Kilogram je jedina osnovna jedinica koja već u sebi ima ugrađen predmetak. To je zadržano iz povijesnih razloga, nakon što je zaključeno da je jedinica gram presitna i nepraktična. Naziv gram iznikao je od ranijeg naziva "grave", koji je trebao podsjećati na vezu s težinom, ali je ubrzo napušten, vjerojatno zbog nelagode koju su izazivala druga značenja iste riječi.

Definicije osnovnih jedinica u prošlosti više su se puta mijenjale, prateći nove tehnologije i sve preciznije mjerne rezultate. Posebno treba naglasiti elektromagnetske eksperimentalne metode koje su, u godinama nakon 1970., u svijet mjerenja unijele dotad nezapamćenu preciznost. ${ }^{4,5}$ Unatoč velikom uspjehu s kojim su veličine i jedinice sustava SI primjenjivane u prirodnim znanostima, inženjerstvu, industriji, trgovini i školstvu, mnogi su stručnjaci smatrali da su njihove definicije neprikladne i neujednačene te da ih treba zamijeniti logičnijim sustavom koji će se temeljiti na prirodnim konstantama.

Mjerne veličine masa i količina (množina) tvari imaju posebnu važnost u kemiji i kemijskom inženjerstvu. Promjene definicija njihovih jedinica - kilograma i mola - pažljivo su pripremane više od dva desetljeća. ${ }^{6-8}$ Ključnu su ulogu pri tome odigrale dvije organizacije: BIPM (Bureau international des poids et mesures) u Francuskoj i NIST (Na- 
tional Institute for Standards and Technology) u Sjedinjenim Američkim Državama, uz uspješnu suradnju s brojnim drugim svjetskim institutima i laboratorijima. Temeljni cilj tih istraživanja bilo je precizno mjerenje prirodnih konstanti na kojima se planiralo graditi nov usavršeni sustav mjernih jedinica. U ovom će članku biti riječi o novim definicijama jedinica sustava SI (posebno kilograma i mola), o prirodnim jedinicama koje leže u pozadini tih promjena te o zadatcima s kojima se pri njihovu tumačenju susreću nastavnici kemije u školskoj i fakultetskoj nastavi.

\section{Nove definicije osnovnih jedinica sustava SI}

Od 20. svibnja 2019. svih sedam osnovnih jedinica definirano je preko sedam prirodnih konstanti, $v_{\mathrm{C} s}, \mathrm{c}, h, \mathrm{e}, k_{\mathrm{B}}, \mathrm{N}_{\mathrm{A}}$ i $K_{\text {cd. }}$. Njihove vrijednosti i značenja vidljivi su iz tablice $1, \mathrm{u}$ kojoj su navedene stare i nove definicije sedam osnovnih jedinica sustava $\mathrm{SI}$, a to su sekunda, metar, kilogram, amper, kelvin, mol i kandela. Riješe li se algebarske jednadžbe implicitno sadržane u novim definicijama, dobivaju se pripadni matematički izrazi, također navedeni u tablici 1.

Tablica 1 - Stare i nove definicije osnovnih jedinica Međunarodnog sustava SI

Table 1 - Old and new definitions of the base units of the International System of Units (SI)

Stare definicije
(do 20. svibnja 2019.)
Sekunda
Od 1967. godine definira se kao trajanje
9192631770 perioda zračenja koje nastaje
pri prijelazu između dviju hiperfinih razina
Osnovnoga stanja atoma Cs 133.
Metar
Od 1983. godine definira se kao duljina
puta koji u vakuumu prijeđe svjetlost za
1/299792458 sekunde.
Kilogram
Od 1901. godine kilogram je definiran
kao masa prauzorka koji je načinjen od
platine i iridija. Prauzorak je smješten u
Međunarodnome uredu za utege i mjere u
Sèvresu pokraj Pariza. Kilogram je decimalni
višekratnik jedinice gram.

\section{Amper}

Od 1948. godine amper je definiran kao struja koja teče dvama usporednim, beskonačno dugačkim i ravnim vodičima zanemarivoga presjeka u vakuumu koji su međusobno udaljeni jedan metar a među vodičima djeluje sila od $2 \cdot 10^{-7} \mathrm{~N}$ po metru duljine.

\section{Kelvin}

Od 1967. godine kelvin je definiran kao 1/273,16 temperature trojne točke vode a po iznosu je jednak Celzijevu stupnju.

\section{Mol}

Od 1971. godine mol je definiran kao količina tvari koja sadržava broj istovjetnih jedinka (atoma, molekula, elektrona ili drugih čestica) jednak broju atoma u 0,012 kilograma izotopa ugljika 12C.

\section{Kandela}

Od 1979. godine kandela je definirana kao svjetlosna jakost u danome pravcu izvora koji odašilje monokromatsko zračenje frekvencije $5,4 \cdot 10^{14} \mathrm{~Hz}$ i čija je energetska jakost zračenja u tom pravcu (1/683) W po steradijanu.
Nove definicije

(od 20. svibnja 2019.)

Sekunda, znak s, jedinica je sustava SI za vrijeme. Definira se

tako da se uzme da je zadana numerička vrijednost cezijeve

frekvencije $\Delta v_{\mathrm{C} s}$, tj. frekvencije hiperfinoga prijelaza nesmetanoga osnovnog stanja atoma cezija 133 jednaka 9192631770 kad je izražena u jedinici $\mathrm{Hz}$ jednakoj s $\mathrm{s}^{-1}$.

$$
1 \mathrm{~s}=\left(1 / \Delta v_{\mathrm{Cs}}\right) \cdot 9192631770
$$

Metar, znak $\mathrm{m}$, jedinica je sustava SI za duljinu. Definira se tako

da se uzme da brzina svjetlosti u vakuumu $\boldsymbol{c}$ ima vrijednost

299792458 kad je izražena u jedinici $\mathrm{m} \mathrm{s}^{-1}$, pri čemu je sekunda definirana s pomoću cezijeve frekvencije $\Delta v_{\text {Cs }}$. $1 \mathrm{~m}=\left(c / \Delta v_{\mathrm{Cs}}\right) \cdot 30,663319$

Kilogram, znak kg, jedinica je sustava SI za masu. Definira se tako da se uzme da je fiksna numerička vrijednost Planckove konstante $h$ jednaka 6,626 $07015 \cdot 10^{-34} \mathrm{kad}$ je izražena u jedinici J s, što je jednako $\mathrm{kg} \mathrm{m}^{2} \mathrm{~s}^{-1}$, pri čemu su metar i sekunda definirani s pomoću c i $\Delta v_{\mathrm{Cs}}$.

$1 \mathrm{~kg}=\left(h \Delta v_{\mathrm{CS}} / \mathrm{c}^{2}\right) \cdot 1,4755214 \cdot 10^{40}$

Amper, znak A, jedinica je sustava SI za električnu struju.

Definira se tako da se uzme da je fiksna numerička vrijednost elementarnoga naboja e jednaka 1,602 $176634 \cdot 10^{-19} \mathrm{kad}$ je izražena u jedinici $C$ koja je jednaka $A s$, pri čemu je sekunda

$\mathrm{e} \Delta v_{\mathrm{CS}}$ definirana s pomoću $\Delta v_{\mathrm{CS}}$

$$
1 \mathrm{~A}=\left(\mathrm{e} \Delta v_{\mathrm{CS}}\right) \cdot 6,789687 \cdot 10^{8}
$$

Kelvin, znak K, jedinica je sustava SI za termodinamičku temperaturu. Definirana je tako da se uzme da je fiksna numerička vrijednost Boltzmannove konstante $k_{\mathrm{B}}$ jednaka $1,380649 \cdot 10^{-23} \mathrm{kad}$ je izražena u jedinici J $\mathrm{K}^{-1}$, što je jednako $\mathrm{kg} \mathrm{m}^{2} \mathrm{~s}^{-2} \mathrm{~K}^{-1}$, pri čemu su kilogram, metar i sekunda definirani s pomoću konstanti $h$, $c$ i $\Delta v_{\mathrm{CS}}$.

$$
1 \mathrm{~K}=\left(h \Delta v_{\mathrm{CS}} / k_{\mathrm{B}}\right) \cdot 2,2666653
$$

Prirodna jedinica

$$
\frac{1}{\Delta v_{\mathrm{CS}}}
$$

$$
\frac{C}{\Delta v_{\mathrm{Cs}}}
$$

(n)

$$
\frac{h \Delta v_{\mathrm{Cs}}}{c^{2}}
$$

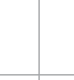


Poučan grafički prikaz novih definicija dan je na slici 1.

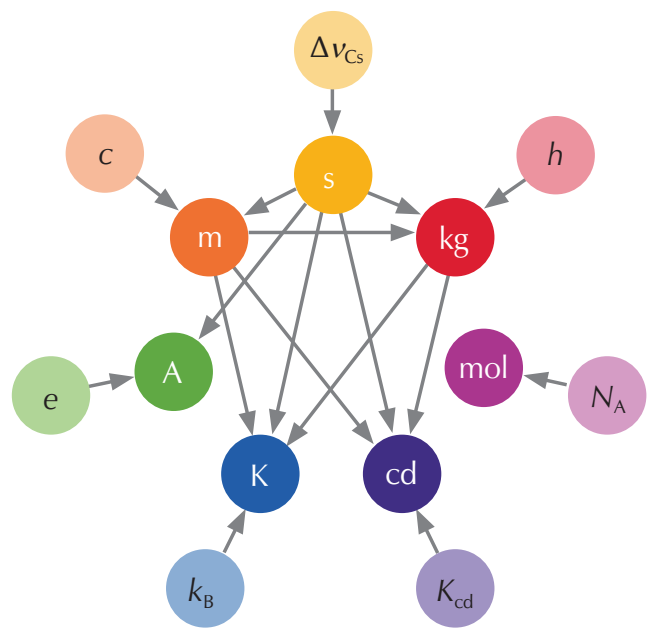

Slika 1 - Prikaz novih definicija osnovnih jedinica SI i njihove veze s odabranih sedam prirodnih konstanti ${ }^{1}$

Fig. 1 - Diagram representing redefined SI base units and their relation to the seven natural constants ${ }^{1}$

Karakteristično je da se svaka jedinica može iskazati kao umnožak neke kombinacije odabranih prirodnih konstanti i posebnog numeričkog faktora. , $^{2,9-11}$ Time je osigurano da se jedinice definirane na novi način podudaraju sa starim jedinicama sustava SI. Dobivene kombinacije konstanti, eksplicitno navedene $u$ trećem stupcu tablice 1 , imaju posebnu važnost: možemo ih smatrati novim prirodnim jedinicama. To je bila i jedna od glavnih motivacija za uvođenje novog pristupa definicijama, jer su znanstvenici odavno zahtijevali da sustavi jedinica koje se rabe u praksi budu utemeljeni na prirodnim konstantama poznatima iz fizike. $U$ starom sustavu to je već bilo postignuto s jedinicama za vrijeme, udaljenost i svjetlosnu jakost. lako iskazane drugačijim riječima, njihove su nove definicije istovjetne starima. Definicije izvedenih jedinica mogu se izvesti iz definicija u tablici $1 .{ }^{9-11}$

Za neke od izvedenih veličina prirodne su jedinice znatno jednostavnije od onih za osnovne veličine. Tako se za električni naboj dobiva prirodna jedinica e, za kutnu količinu gibanja (zamah) $h$, a za brzinu c. Zbog te jednostavnosti moglo bi se predložiti da se cijeli sustav jedinica iznova definira počevši od nekog drugog niza osnovnih jedinica. To bi bilo ispravno, ali ne i praktično. Osim ostalog, time bi se mijenjao i sustav osnovnih mjernih veličina, a on je utvrđen u Normama ISO-IEC 80000 koje na taj način mogu ostati nepromijenjene. Treba još napomenuti da se taj novouvedeni sustav razlikuje od drugih otprije poznatih sustava prirodnih jedinica, primjerice od atomskog (koji za prirodnu jedinicu duljine rabi Bohrov polumjer $a_{0}$ ) ili Planckovog (u kojem je jedna od konstanti opća gravitacijska konstanta $G)$.

\section{Kilogram}

Pogledom u stare definicije uočava se da je kilogram sve do 2019. godine ostao jedina jedinica definirana predmetnim prauzorkom. Bio je to čuveni prototip (International Prototype of the Kilogram, IPK) u obliku valjka visine i promjera osnovice $39 \mathrm{~mm}$, načinjen od platine i iridija, koji se od 1889. pod staklenim zvonom čuvao u Međunarodnom uredu za utege i mjere u Sèvresu kraj Pariza (slika 2). Uz njega je bilo i njegovih šest službenih kopija. Usporedbom njihovih masa primijećeno je da se masa prauzorka s vremenom smanjuje. Razlike su se iskazivale u mikrogramima, ali s obzirom na visoku preciznost koja se danas očekuje pri mjerenjima mase, to je dovoljno da se uzorak počne smatrati nepouzdanim. $U$ nekoj nepredviđenoj katastrofi moglo bi doći do teškog oštećenja pa i uništenja tog predmeta. To je bio još jedan dobar razlog da se potraži nov način definiranja pomoću nečeg doista stalnog kao što je prirodna konstanta, neka od onih koje se pojavljuju u zakonima fizike.

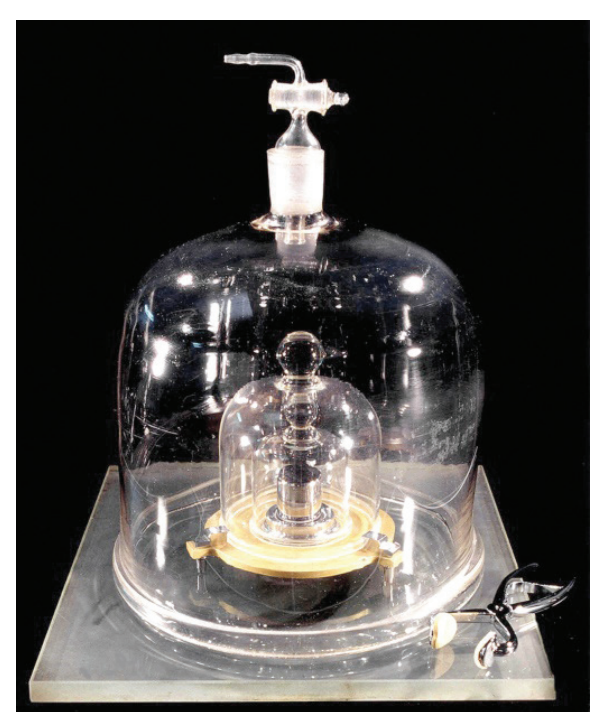

Slika 2 - Prauzorak kilograma (IPK) ${ }^{3}$

Fig. 2 - Prototype of the kilogram (IPK)

Iskristalizirala su se dva prijedloga: prvi je bio da se, zahvaljujući preciznim elektromagnetskim vagama, mjerenje mase poveže s Planckovom konstantom $h$; drugi je predlagao definiranje kilograma pomoću brojanja čestica u uzorku načinjenom od kristala silicija-28.

Prvi se postupak temeljio na mjerenjima mase vatnom (Kibbleovom) vagom (slika 3), koja je zahvaljujući makroskopskim kvantiziranim pojavama (kvantnom Hallovom učinku i Josephsonovom učinku) povezala masu s Planckovom konstantom. ${ }^{3,12}$ Kibbleova vaga mjeri masu tako da njezinu težinu uspoređuje s elektromagnetskom silom. Postupak se sastoji od dvaju koraka. U prvom strujna petlja duljine $L$ kojom teče električna struja I miruje u magnetskom polju gustoće toka $B$. Javlja se elektromagnetska (Lorentzova) sila $F=I B L$ koja uravnotežuje težinu utega mase $M$ :

$$
I B L=M g .
$$




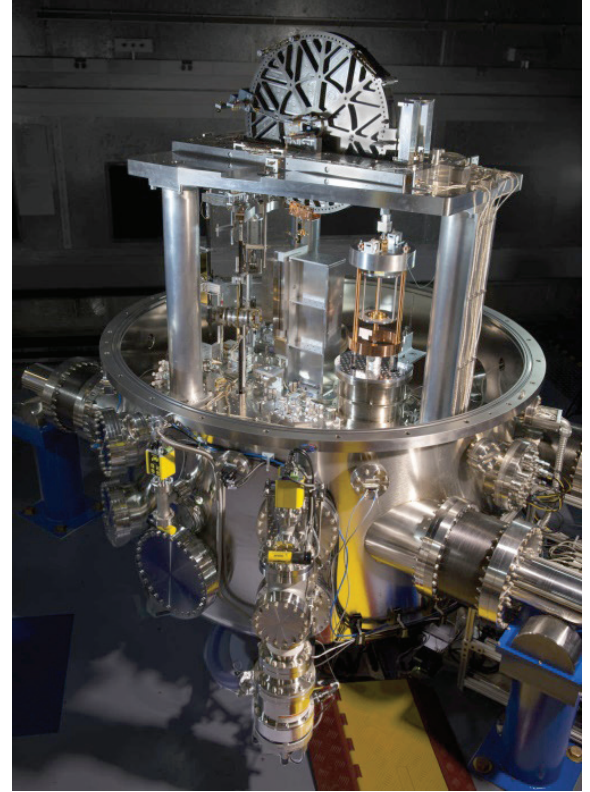

Slika 3 - Kibbleova (vatna) vaga koja masu tijela mjeri s pomoću Planckove konstante $h^{3}$

Fig. 3 - Kibble's (watt) balance designed to determine the mass using Planck's constant $h^{3}$

$U$ drugom se koraku strujna petlja giba brzinom $v$, a zbog Faradayeva zakona indukcije u njoj se inducira električni napon $U$ proporcionalan brzini $v: U=v B L$. Uz točno mjerenje brzine $v$ i lokalne gravitacijske akceleracije $g$, Kibbleova (vatna) vaga mjeri umnožak UI koji je proporcionalan Planckovoj konstanti $h$. Napokon se dobiva jednakost

$$
M=\frac{U I}{v g}=\text { konst. } \cdot h
$$

i time se određivanje mase u potpunosti oslanja na Planckovu konstantu $h$, poznatu iz zakona fizike koji tumače kvantnomehaničku strukturu tvari i prirodu svjetlosti.

U drugom nizu eksperimenata, nazvanom projektom Avogadro, ${ }^{3,13}$ iskorištena je iznimno pravilna kristalna struktura izotopa silicija-28, od kojeg je načinjena glatka kugla promjera 94 mm - kako neki kažu, najokrugliji i najizglačaniji predmet na svijetu (slika 4).

Prevladala je prva mogućnost, i danas je kilogram definiran s pomoću Planckove konstante $h$. Međutim, rezultati koji su proizašli iz projekta Avogadro nisu bili uzaludni: moglo ih se korisno primijeniti u definicijama i dogovorima vezanima uz količinu tvari i njezinu jedinicu mol.

\section{Mol}

Nova definicija mola iznimno je jednostavna i razumljiva. Jedan mol nekih jedinki (atoma, molekula, elektrona itd.) znači 602214076000000000000000 tih jedinki. Ako jedinki ima dvaput više od toga broja, onda su to dva mola.

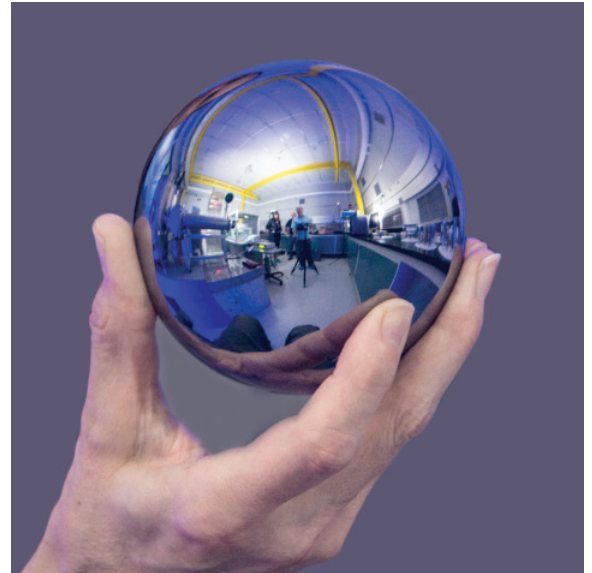

Slika 4 - Glatka kugla od silicija-28 načinjena u okviru projekta Avogadro ${ }^{3}$

Fig. 4 - The smooth crystal ball of silicon-28 made within the Avogadro project ${ }^{3}$

U svakodnevnom životu slično se broj nekih jednakih predmeta iskazuje tucetima. Kad je u kutiji 12 jaja, to je jedan tucet. Ako ih ima 36, to su tri tuceta. Samo što atomskih čestica u sličnoj kutiji ima mnogo, mnogo više, pa ih se ne opisuje s pomoću tuceta, nego se iskazuju brojem molova $n$. Time se mjeri veličina koja se naziva "količina tvari". (Upravo zato što tu ima tako mnogo čestica, uvriježio se i dodatni naziv "množina tvari".)

Broj koji je za mol ono što je 12 za tucet, obično se piše kao 6,02214076 $\cdot 10^{23}$ i zove se Avogadrov broj. Prirodna konstanta koja određuje mol u novoj definiciji zove se Avogadrova konstanta i glasi: $N_{\mathrm{A}}=6,02214076 \cdot 10^{23} \mathrm{~mol}^{-1}$. Na slici 1, koja prikazuje nove definicije osnovnih jedinica SI uočljivo je da je sada mol jedina od svih sedam osnovnih jedinica definirana potpuno neovisno o ostalim jedinicama i izravno je vezana samo s jednom prirodnom konstantom - Avogadrovom konstantom. Treba naglasiti da u novoj definiciji Avogadrova konstanta ima fiksnu vrijednost, dok je u prijašnjim definicijama bila podvrgnuta mjerenjima i određena s izvjesnom pogreškom.

\section{Kilogram i mol u nastavi kemije}

Donekle začuđuje činjenica da su u nastavi kemije, i u bližoj i u daljnjoj prošlosti, pojmovi mola i količine (množine) tvari bili posebno teški i zahtjevni. U pedagoškoj literaturi ima mnogo primjera koji pokazuju da su učenici zbunjeni tim pojmovima i da ih dobro ne razumiju, ${ }^{14}$ pa zato imaju teškoća pri rješavanju zadataka iz stehiometrije. Detaljnije su analize pokazale da je učeničko neznanje često posljedica zbunjenosti samih nastavnika. Jedan od razloga je i u tome što se "količinu tvari" intuitivno prevodilo kao masu, a tome je u prilog išla i sada već zastarjela definicija mola. Pojam mola je možda neuhvatljiv i zbog samog Avogadrova broja, koji je tako velik u usporedbi s brojevima iz svakodnevice da mnogima ostaje nejasan i nepredočljiv. Tu je i sam povijesni razvitak tih pojmova: povijest mola 
isprepletena je s poviješću molne mase, atomske mase, atomske jedinice mase (daltona), količine (množine) tvari, Avogadrova broja i slično. Ti i drugi njima srodni pojmovi pojavili su se u raznim povijesnim trenutcima, a dio njih i u doba dok još nije bilo potvrđeno postojanje atoma niti je bila dokazana istinitost atomskih teorija.

Prvu tablicu standardnih "atomskih težina" (atomskih masa) objavio je 1805. godine John Dalton (1766. - 1844.). Temeljila se na sustavu u kojem je relativna atomska masa vodika imala zadanu vrijednost 1 . Ostale atomske mase oslanjale su se na stehiometrijske omjere kemijskih reakcija i spojeva; to je uvelike pomoglo njihovom prihvaćanju. Kemičar nije morao priznavati atomsku teoriju (u to vrijeme nedokazanu hipotezu) da bi se služio dostupnim tablicama. Amedeo Avogadro (1776. - 1856.) je 1811. godine postavio hipotezu da jednake količine plinova pri istoj temperaturi i tlaku sadrže jednak broj molekula. Avogadro je također pronicljivo uočio da jednostavni plinovi nisu sastavljeni od pojedinačnih atoma, već od molekula koje tvore dva ili više atoma. Zanimljivo je da je trebalo proći više od pola stoljeća do priznanja Avogadrovih otkrića. Avogadro je bio talijanski plemić, školovani pravnik i državnik u Torinu. Matematiku, fiziku i kemiju studirao je privatno te ih je niz godina i predavao na Torinskom sveučilištu. Objavljivao je svoja otkrića, ali nije osobno sudjelovao u burnim znanstvenim zbivanjima svojega vremena. Za otkrivanje Avogadrovih djela i promicanje njegovih ideja posebno je zaslužan talijanski znanstvenik Stanislao Cannizzaro (1826. - 1910.). Ključnu ulogu u preciznom određivanju atomskih masa odigrao je Jöns Jakob Berzelius (1779. - 1848.). Prvi je upotrijebio molnu masu kisika kao normu na koju su se oslanjale druge molne mase. Kisik je bio koristan jer, za razliku od vodika, tvori spojeve s većinom ostalih elemenata, posebno metala. Berzelius je iznimno precizno, klasičnim metodama, izmjerio mnoge relativne atomske mase; njegove su tablice još dugo ostale u upotrebi. Njegovo su djelo nastavili mnogi drugi kemičari, rješavajući stehiometrijske probleme brojnih kemijskih spojeva. $^{15}$

Upotreba atomske mase udomaćila se do 1860. kad je održan čuveni kongres u Karlsruheu. Kongres se priklonio definiranju relativne atomske mase vodika kao 1. Na razini preciznosti mjerenja $u$ to vrijeme - relativne nesigurnosti od oko $1 \%$ - to je bilo brojčano ekvivalentno normi kisika-16. Međutim, napretkom analitičke kemije i potrebom za sve većom preciznošću, postalo je sve očiglednije da kisik ima prednost pri utvrđivanju primarne norme za atomsku masu. Samo ime mol prijevod je imena njemačke jedinice Mol, koje je 1894. godine, polazeći od latinske riječi moles (težina, breme, gromada), skovao kemičar Wilhelm Ostwald (1853. - 1932.).

Kongres u Karlsruheu bio je prvi međunarodni sastanak kemičara te da je doveo do kasnijeg osnivanja Međunarodne unije čiste i primijenjene kemije (IUPAC). Nakon kongresa u Karlsruheu napokon su usvojene vrijednosti relativnih molnih masa: približno 1 za vodik,
12 za ugljik, 16 za kisik i tako dalje. To se temeljilo na spoznaji da su određeni elementi, poput vodika, dušika i kisika, sastavljeni od dvoatomnih molekula, a ne od pojedinačnih atoma. Tijekom 1960-ih definicija utemeljena na kisiku-16 zamijenjena je definicijom koja se temelji na ugljiku-12. Nakon toga je Međunarodni ured za utege i mjere odredio mol kao "količinu tvari koja sadrži toliko elementarnih jedinki koliko ima atoma u 0,012 kilograma ugljika-12". Ta je definicija vrijedila sve do donošenja novih definicija koje su stupile na snagu 20. svibnja 2019.

\section{Kilogram i mol u numeričkim primjerima}

S pojmom mola učenici se prvi put susreću u fizici idealnog plina. $U$ idealnom plinu ukupna masa $m$ atoma ili molekula, njihov broj $N$ i atomska ili molna masa $\left(M_{\mathrm{a}}\right)$ povezani su izrazima za količinu tvari $n$ :

$$
n=\frac{N}{N_{\mathrm{A}}} \text { i } n=\frac{m}{M_{\mathrm{a}}} .
$$

Plinska jednadžba glasi

$$
p V=n R T
$$

gdje su $V$ volumen, $T$ temperatura, $p$ tlak i $R$ opća plinska konstanta. Za "normirane uvjete" ( $p=p_{\mathrm{a}}=101325 \mathrm{~Pa}, T$ $=273,15 \mathrm{~K})$ jedan mol idealnog plina zauzima volumen

$$
V=\frac{n R T}{p_{\mathrm{a}}}=\frac{1 \mathrm{~mol} \cdot 8,314 \mathrm{~J} \mathrm{~mol}^{-1} \mathrm{~K}^{-1} \cdot 273,15 \mathrm{~K}}{101325 \mathrm{~Pa}}=22,41 \mathrm{I} .
$$

Definicija mola podrazumijeva da su čestice međusobno neovisne; to je ispunjeno u plinovima male gustoće. Međutim, u pravilnim kristalima one su veoma uredno razmještene i također dopuštaju brojanje jedinki, atoma ili molekula. Time se vraćamo na najglatkiji i najokrugliji predmet na Zemlji, na kuglu načinjenu od silicija-28 u projektu Avogadro (slika 4). Mnogi su kemičari očekivali da će - nakon što predmetni prauzorak kilograma ode u povijest - nova definicija kilograma biti uvedena preko brojanja atoma u kristalu silicija. lako je ta ideja napokon odbačena, bitno je utjecala na oblikovanje nove definicije mola s fiksnom vrijednošću Avogadrova broja.

Kristal silicija-28, obogaćen tako da gotovo i nema primjesa drugih izotopa ni drugih elemenata, ima iznimno pravilnu strukturu, identičnu onoj dijamanta (slika 5), u kojoj strukturni fragment od 18 odabranih susjednih atoma možemo opisati kockom brida $a=0,5430 \mathrm{~nm}$. Na sredini svake od šest ploha kocke nalazi se po jedan atom silicija, kao i na svakom od osam vrhova, dok su u unutrašnjosti kocke još četiri atoma. Plohe, bridove i vrhove kocka dijeli sa susjednim kockama, pa je broj atoma koji pripada pojedinoj jediničnoj ćeliji osam. Usmjerenost kovalentnih veza među atomima može se opisati tetraedrom a kut koji zatvaraju kemijske veze iznosi 109,47 . 


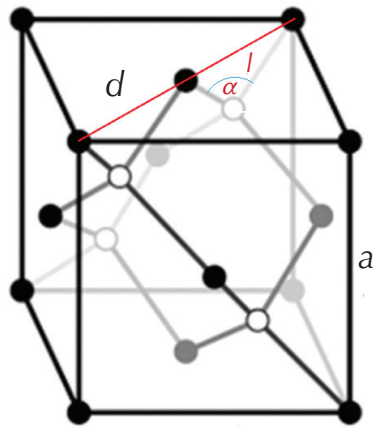

Slika 5 - Kristalna struktura silicija-28

Fig. 5 - Crystal structure of silicon-28

1) U prvom zadatku cilj je, za molekulu koja ima jednake atome u središtu i na vrhovima pravilnog tetraedra stranice a, uz pomoć geometrijskih i trigonometrijskih izraza,

a) izračunati već spomenuti kut $\alpha$ između kemijskih veza i

b) izračunati duljinu / kemijske veze u kristalu silicija-28.

\section{Upute i rješenja:}

Tetraedar je pravilna trostrana piramida kojoj su sve plohe jednakostranični trokuti stranice $s$. Visinu pojedinog trokuta označimo s $b$, a visinu piramide s $h$ (slika 6). Da bismo dobili središnju točku (težište) tetraedra, u kojoj se također nalazi atom, podijelimo visinu $h$ na dva dijela: donji (manji) dio nazovimo $y$, a gornji (veći) $x$. Pretpostavili smo dakle da je $x+y=h$. Promatrajući odgovarajuće trokute (slika 7), možemo izraziti $b, h$, x i y pomoću s i dobivamo:

$$
b=\frac{s \sqrt{3}}{2}, h=\frac{s \sqrt{6}}{3}, x=\frac{s \sqrt{6}}{4} \mathrm{i} y=\frac{s \sqrt{6}}{12} .
$$

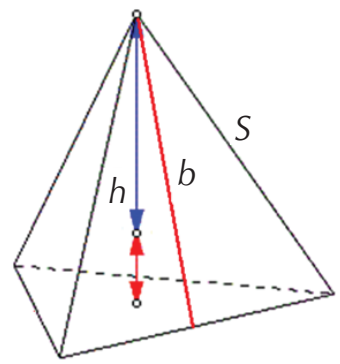

Slika 6 - Pravilni tetraedar

Fig. 6 - Regular tetrahedron

Treći crtež na slici 7 sadrži i tupokutni trokut s kutom $\alpha$ koji tražimo. Podijelimo li ga na dva jednaka pravokutna trokuta, dobivamo

$$
\sin \frac{\alpha}{2}=\frac{s}{2 x}=\sqrt{\frac{2}{3}}=0,816497, \frac{\alpha}{2}=54,736,
$$

odakle proizlazi traženi kut

$$
\alpha=109,47^{\circ} .
$$

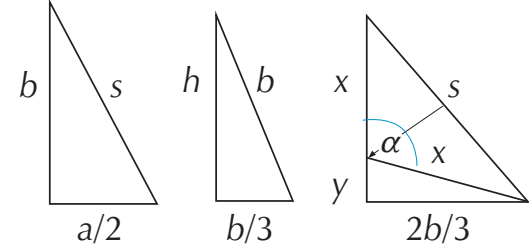

Slika 7 - Određivanje kuta u tetraedarskoj strukturi

Fig. 7 - Determination of the angle in the tetrahedral structure

Ujedno možemo provjeriti i tvrdnju da središte tetraedra dijeli njegovu visinu u omjeru $3: 1$,

$$
\frac{x}{y}=\frac{\frac{s \sqrt{6}}{4}}{\frac{s \sqrt{6}}{12}}=3 .
$$

b) Duljinu veze u kristalu silicija-28 izračunat ćemo s pomoću jednakokračnog tupokutnog trokuta, kojem su dvije stranice jednake duljini veze $I$, dok je konstanta rešetke duljina brida kubne ćelije $a=0,5430 \mathrm{~nm}$. Dulja stranica $g$ tog trokuta jednaka je polovini dijagonale $d$ kvadratne plohe kristalne ćelije (slika 6)

$$
g=\frac{d}{2}=\frac{a \sqrt{2}}{2} .
$$

Proizlazi

$$
\sin \frac{\alpha}{2}=\frac{\frac{g}{2}}{l}
$$

a za duljinu veze dobiva se

$$
I=\frac{\frac{g}{2}}{\sin \frac{\alpha}{2}}=\frac{0,38396 \mathrm{~nm}}{2 \sin 54,736^{\circ}}=0,235 \mathrm{~nm} .
$$

2) Kako odrediti Avogadrovu konstantu s pomoću kristala silicija-28? Zamislite da imate kocku mase $m=1 \mathrm{~kg}$ načinjenu od kristalnog silicija-28 gustoće $\rho=2324 \mathrm{~kg} \mathrm{~m}^{-3}$ i da poznajete njegova kristalna svojstva (konstantu rešetke $a=0,5430 \mathrm{~nm}$ i broj atoma po kristalnoj ćeliji $N_{1}=8$ ). Kako biste iz tih podataka izračunali Avogadrovu konstantu?

Uputa i rješenje:

Molna masa silicija-28 jednaka je $M_{\mathrm{a}}=28 \mathrm{~g} \mathrm{~mol}^{-1}$. Broj atoma u kocki jednak je

$$
N=\frac{V \cdot 8}{V_{1}}=\frac{\frac{m}{\rho} \cdot 8}{V_{1}}=\frac{8 m}{\rho a^{3}}
$$

gdje je $V$ volumen kocke, a $V_{1}$ volumen jedne kristalne ćelije. Izraženo masom i molnom masom 


$$
N=\frac{m}{M_{a}} \times N_{A}
$$

Avogadrova je konstanta

$$
\begin{aligned}
N_{A}=\frac{8 M_{a}}{\rho a^{3}}= & \frac{8 \cdot 28 \cdot 10^{-3} \mathrm{kgmol}^{-1}}{2324 \mathrm{kgm} \mathrm{m}^{-3} \cdot\left(0,5430 \cdot 10^{-9} \mathrm{~m}\right)^{3}}= \\
& =6,020 \cdot 10^{23} \mathrm{~mol}^{-1} .
\end{aligned}
$$

Tom su metodom kemičari istraživali moguće pristupe novoj definiciji kilograma i mola. ${ }^{16}$ Za dobivanje točnijih vrijednosti bile su potrebne dodatne pretpostavke i mnoge prilagodbe eksperimenta.

3) Da bismo učenicima približili pojmove mola i količine tvari, poželjno je naći neku zanimljivu usporedbu s tvarima iz svakodnevnog života, ${ }^{17} \mathrm{~s}$ nekim zrnjem koje susrećemo svakodnevno i koje bismo mogli izbrojati - primjerice zrnima riže.

a) Izračunajte volumen jednog mola riže.

b) Ako se jedan mol zrna riže jednoliko rasporedi po cijelom kopnu na Zemlji, koliko će visok biti dobiveni sloj?

c) Kamo bismo morali odvesti studente da im pokažemo jedan mol zrna riže?

\section{Upute i rješenja:}

a) Najprije računamo koliki je volumen jednog mola rižinih zrna. Treba nam mala mjerica od nekoliko mililitara. Ubacimo rižu do oznake $1 \mathrm{ml}$ i prebrojimo zrna - ona mogu biti veća ili manja. Vjerojatno će ih biti oko 50. Napišimo: $N_{1}=50, V_{1}=10^{-6} \mathrm{~m}^{3}$. Vrijedi omjer:

$$
\frac{V}{V_{1}}=\frac{1 \mathrm{~mol} \times \mathrm{N}_{\mathrm{A}}}{N_{1}}
$$

Dobivamo

$$
V=\frac{6,022 \cdot 10^{23} \cdot 10^{-6} \mathrm{~m}^{3}}{50}=1,2044 \cdot 10^{16} \mathrm{~m}^{3} .
$$

b) Površina kopna na Zemlji iznosi $P_{Z}=1,48939 \cdot 10^{14} \mathrm{~m}^{2}$. Visina sloja riže bila bi

$$
h=\frac{V}{P_{\mathrm{Z}}}=\frac{1,2044 \cdot 10^{16} \mathrm{~m}^{3}}{1,48939 \cdot 10^{14} \mathrm{~m}^{2}} \approx 81 \mathrm{~m} .
$$

c) Gdje se može vidjeti jedan mol riže? Nigdje! Toliko riže nije proizvedeno ni tijekom cijele povijesti čovječanstva!

\section{Zaključak}

Epohalni dogovor, kojim su na novi način definirani ne samo kilogram i mol nego i sve ostale osnovne i izvedene jedinice sustava SI, obilježio je 2019. godinu pružajući veliku priliku za brojne i raznovrsne aktivnosti u nastavi fizike i kemije. To mogu biti opisi i analize inovativnih mjernih i mjeriteljskih metoda, ${ }^{3,6,12}$ ali i proračuni izvedenih jedinica i pripadnih numeričkih faktora s pomoću sedam zadanih prirodnih konstanti. ${ }^{9-11} \mathrm{Uz}$ ispravan pedagoški i metodički pristup, tema mjernih jedinica nosi u sebi potencijal za kreativne rasprave te može obogatiti srednjoškolsku i sveučilišnu nastavu temeljnih prirodnih znanosti, ali i sadržaje društvenih i humanističkih predmeta.

\section{Literatura \\ References}

1. 2019 redefinition of SI base units, https://en.wikipedia.org/ wiki/2019_redefinition_of_SI_base_units.

2. BIPM Brochure, $9^{\text {th }}$ edition, "Le Système international d'unités, The International System of Units", https://www. bipm.org/utils/common/pdf/si-brochure/SI-Brochure-9.pdf.

3. SI Redefinition, Turning Point for Humanity: Redefining the World's Measurement System, https://www.nist.gov/si-redefinition/introduction-redefining-worlds-measurement-system.

4. The Nobel Prize in Physics, 1973. http://www.nobelprize. org/nobel_prizes/physics/laureates/1973.

5. The Nobel Prize in Physics, 1985. http://www.nobelprize. org/nobel_prizes/physics/laureates/1985/.

6. S. Knotts, P. J. Mohr, W. D. Phillips, An Introduction to the New SI, The Physics Teacher 55 (1) (2017) 16-21, doi: https://doi.org/10.1119/1.4972491.

7. R. S. Davis, What Is a Kilogram in the Revised International System of Units (SI)?, J. Chem. Educ. 92(10) (2015) 16041609, doi: https://doi.org/10.1021/acs.jchemed.5b00285.

8. V. Lopac, Prošlost i budućnost kilograma - koncepti mase i težine u suvremenoj nastavi fizike; Zbornik X. hrvatskog simpozija o nastavi fizike, Zadar, 27. - 29. travnja 2011., HFD, Zagreb, 2011., str. 102-107

9. V. Lopac, D. Hrupec, What exactly are the new definitions of kilogram and other SI units?, Phys. Teach. 58 (1) (2020) 5860, doi: https://aapt.scitation.org/doi/10.1119/1.5141976, https://www.researchgate.net/publication/338138786 What_Exactly_Are_the_New_Definitions_of_Kilogram and_Other_SI_Units.

10. V. Lopac, Nove definicije jedinica Međunarodnoga sustava SI i njihova veza s prirodnim konstantama, Svijet po mjeri $\mathbf{4}$ (2018) 39-44. 
11. V. Lopac, 2019. - godina epohalnih promjena u definicijama mjernih jedinica Međunarodnoga sustava SI, Zbornik XIV. hrvatskog simpozija o nastavi fizike, Zadar 23. - 25. travnja 2019., HFD, Zagreb 2019., str. 13-19.

12. L. S. Chao, S. Schlamminger, D. B. Newell, J. R. Pratt, F. Seifert, X. Zhang, G. Sineriz, M. Liu, D. Haddad, A LEGO Watt balance: An apparatus to determine a mass based on the new SI, Am. J. Phys. 83 (2015) 913-923, doi: https://doi. org/10.1119/1.4929898.

13. "International Avogadro Project", https://www.bipm.org/en/ bipm/mass/avogadro/.

14. C. Furió, R. Azcona, J. Guisasola: The Learning and Teaching of the Concepts Amount of substance and Mole: a Review of the Literature, Chem. Educ. Res. Pract. 3 (3) (2002) 277 292, doi: https://doi.org/10.1039/B2RP90023H.

15. D. Grdenić, Povijest kemije, Školska knjiga i Novi Liber, Zagreb, 2001., str. 525-568.

16. P. Becker, H. Friedrich, K. Fujii, W. Giardini, G. Mana, A. Picard, H.-J. Pohl, H. Riemann, S. Valkiers, The Avogadro constant determination via enriched silicon-28, Meas. Sci. Technol. 20 (2009) 092002, doi: https://doi.org/10.1088/09570233/20/9/092002.

17. One Mole is A Lot of Things (modified from Dave Tanis), https://betterlesson.com/community/document/5892/onemole-is-a-lot-of-things.

\section{SUMMARY \\ Kilogram and Mole in a New Attire - On Radical Changes in the International System of Units (SI) \\ Vjera Lopac}

At the end of the year 2018, news of a radical transformation of the International System of Units (SI) spread worldwide. Particular excitement was caused by the abandonment of the 140-year-old prototype of kilogram, the base SI unit of mass, stored under the glass bell in Sèvres near Paris, France, and by the introduction of a new definition of kilogram using the quantum-mechanical Planck constant $h$. The changes were accepted at the $26^{\text {th }}$ session of the General Conference on Weights and Measures (CGPM) held in Versailles, France, on November 18, 2018, and entered into force on May 20, 2019. In the new definitions the SI units are derived by means of seven natural constants, $v_{\mathrm{C} s}, c, h, e, k_{\mathrm{B}}, N_{\mathrm{A}}$, and $K_{\mathrm{cd}}$. The article presents the old and the new definitions of the seven base units of the SI system together with the mathematical expressions obtained by solving algebraic equations implicitly contained in the new definitions. The newly defined set of natural units for the base and derived quantities is discussed. The properties and the history of units kilogram and mole as well as the educational aspects of their interpretation are given special attention. Some selected numerical examples are proposed for use in the high school and university chemistry classes.

\section{Keywords}

Chemistry education, International System of Units (SI), kilogram, mole, tetrahedron, crystal structure, silicon-28, natural constants, natural units

Department of Physics, Faculty of Chemical Engineering and Technology, University of Zagreb

Croatia
Professional paper Received December 17, 2019 Accepted February 5, 2020 